\title{
OPPORTUNITIES AND THREATS FOR THE DEVELOPMENT OF AGRIBUSINESS IN UKRAINE IN THE CONTEXT OF MODERN CHALLENGES
}

\author{
${ }^{1}$ Tamara BULYCHEVA, ${ }^{2}$ Kateryna BUTKALIUK, ${ }^{3}$ Tetiana GRYNIUK \\ National Pedagogical Dragomanov University, Kyiv, Ukraine \\ 'lilacsky53@gmail.com, ${ }^{2}$ k-golovaschenko@ukr.net, ${ }^{3}$ tetyanagrinuk@gmail.com
}

\begin{abstract}
The current stage of social development puts on the agenda a number of issues and challenges to which agricultural production, being a sensitive sphere of the Ukrainian economy, should respond. Agribusiness has a powerful resource mechanism that will contribute to the further progress of production activities and the implementation of reforms in the countryside. The article examines the current state of agribusiness in Ukraine, outlining a set of traditional and new factors influencing the development of the industry and determining the peculiarities, including innovation, of its current development. Despite the presence of a whole range of economic, social and political problems, the agriculture of Ukraine is developing rapidly. Entrepreneurship within the framework of the global marketing megatrend Super Food for the production of products of predominantly plant origin, in which the concentration of nutrients is very high, can have a significant impact on the development of domestic agribusiness in the future. Ukrainian craft producers are increasingly joining the international Slow Food movement, which is saving the biodiversity of products, recipes and dishes in the world. This opens up opportunities for domestic producers to participate in foreign festivals and further popularize local agricultural products. However, along with an increase in production and in exports, foreign exchange earnings and tax revenues, the following issues are aggravated: strengthening of agricultural logistics in a "pandemic" economy; adaptation of legislation, regulatory framework and technologies in the European Green Deal (EU Green Deal) increasing the social responsibility of agribusiness, its innovativeness, safety, and competitiveness in the domestic and foreign markets. The unstable situation due to the Covid-19 pandemic led to a reduction in acreage and a decrease in demand for fertilizers. There is a reorientation of farming from expensive mineral fertilizers to cheaper analogues; the exhaustive use of soils could lead to their losses in the near future. Threats have been tracked and the main strategic directions for the development of the agribusiness have been identified, which should be guided by to ensure the profitability of enterprises in the long term.
\end{abstract}

Key words: agribusiness, farms, agricultural machinery, development prospects, COVID-19 pandemic, agroclimatic conditions, European green agreement, agrarian logistics, agrarian science.

DOI: https://doi.org/10.17721/2413-7154/2021.86.30-39

UDC: 338.43 .01

Received: June 03, 2021.

Revised: October 25, 2021.

Accepted: October 29, 2021.

\section{МОЖЛИВОСТІ ТА ЗАГРОЗИ ДЛЯ РОЗВИТКУ АГРОБІЗНЕСУ В УКРАЇНІ У КОНТЕКСТІ СУЧАСНИХ ВИКЛИКІВ}

\author{
'Тамара БУЛИЧЕВА, ${ }^{2}$ Катерина БУТКАЛюК, ${ }^{3}$ Тетяна ГРИНюК
}

Начіональний педагогічний університет імені М. П. Драгоманова, Київ, Україна

'lilacsky53@gmail.com, ${ }^{2}$ k-golovaschenko@ukr.net, ${ }^{3}$ tetyanagrinuk@gmail.com

Анотація: Сучасний етап суспільного розвитку висуває на порядок денний низку питань та викликів, на які має реагувати така чуттєва сфера економіки України як аграрне виробництво. Саме агробізнес має потужний ресурсний потенціал, що сприятиме подальшому прогресу виробничої діяльності та реалізації реформ на селі. У статті досліджено сучасний стан агробізнесу в Україні. Окреслено низку традиційних і нових чинників його розвитку. Проаналізовано їх вплив на особливості функціонування галузі у сучасних умовах. Незважаючи на наявність цілого комплексу проблем економічного, соціального та політичного характеру, сільське господарство України стрімко розвивається. Виявлено, що, поряд зі зростанням виробництва, збільшенням експорту, валютної виручки та податкових надходжень, загострюються такі питання: посилення аграрної логістики в умовах «пандемічної» економіки; адаптації законодавства, нормативної бази та технологій до Європейського зеленого курсу (EU Green Deal); підвищення соціальної відповідальності агробізнесу, його інноваційності, безпечності, конкурентоспроможності на внутрішньому та зовнішньому ринках. Визначено основні стратегічні напрямки розвитку аграрного комплексу, на які варто орієнтуватись для забезпечення прибутковості підприємств на довготривалу перспективу.

Ключові слова: агробізнес, фермерські господарства, сільськогосподарська техніка, перспективи розвитку, пандемія COVID-19, агрокліматичні умови, Європейська зелена угода, аграрна логістика, аграрна наука. 
Постановка проблеми. Наслідком сучасних перетворень в аграрному секторі господарства України є трансформація АПК в агробізнес - нову систему господарювання, орієнтовану на приватну власність і прибуток, реалізовану в умовах ринкового цінотворення, конкуренції, активного застосування новітніх технологій виробництва й управління. Розроблена у суспільній географії концепція агропромислового комплексування недостатньо відображає процеси становлення нових суспільних відносин в аграрному і промисловому секторах на сучасному етапі їх розвитку. Нині у системі міжгалузевої комплексності вкрай важливим $\epsilon$ вивчення різноманітних видів прибуткової діяльності, що формуються в аграрній сфері та у пов'язаних 3 нею дистриб'юторських, логістичних, сервісних та інфраструктурних сегментах господарської діяльності. У сільській місцевості актуалізуються та проявляються нові тенденції адміністративноуправлінського, інвестиційно-інноваційного характеру. Це робить вкрай важливими дослідження аграрного ринку як функціонального середовища агробізнесу з суспільно-географічних позицій.

Процеси становлення агробізнесу в Україні лише входять у сферу інтересів суспільної географії. Проте, ця наука має потужні можливості для обгрунтування шляхів розв'язання багатьох господарських проблем на селі, в тому числі, пов'язаних із формуванням нової територіальної організації аграрного сектора. Це i визначає науковий інтерес суспільно-географічної науки до окреслених аспектів дослідження.

Україна має реально потужні можливості для розвитку аграрного бізнесу через унікально сприятливі природні умови. Держава є значним виробником та експортером багатьох видів сільськогосподарської продукції. Її виробництво $є$ рушійною силою розвитку господарства та зростання добробуту громадян. Проте, за останні декілька років з'явилась низка чинників, які неоднозначно впливають на ефективність функціонування зазначеної сфери, тим самим визначаючи актуальність подальших наукових розвідок.

Аналіз останніх досліджень та публікацій. Попри злободенність визначеної проблематики мусимо визнати, що у науковому середовищі, як i у практичній площині, відсутній єдиний погляд на категорію «агробізнес» та стратегію розвитку останнього 3 позиції сучасних викликів і необхідності підвищення конкурентоспроможності української сільськогосподарської продукції у світі. Вивченню сучасного стану агробізнесу України, його проблем та перспектив розвитку в різні роки присвятили свої дослідження вчені-економісти: 3 питань економічного механізму бюджетної підтримки аграрного сектору (Radchenko, 2017), 3 економіки та організації агропромислових формувань (Khorunzhyi, 2006), засади формування ринку землі та самоадаптації сільських територій в контексті розвитку аграрної сфери (Melnyk et al., 2010), в аспекті обгрунтування інноваційної моделі розвитку аграрного сектору економіки (Sabluk, 2001), аграрна реформа та організаційноекономічні трансформації в сільському господарстві, удосконалення механізму державної підтримки агросектора (Mesel-Veseliak, 2016), загальні питання соціально-економічного розвитку та спеціалізації сільських територій (Orlatyi, 2012), інноваційні трансформації аграрного сектора економіки (Paskhaver, 2009), вирішення стратегічних задач забезпечення продовольчої безпеки країни та конкурентоспроможності агропродовольчого комплексу на зовнішніх та внутрішніх ринках шляхом удосконалення механізмів господарювання та досягнення сталих темпів агровиробництва (Paskhaver, 2009), інституційне забезпечення розвитку i регулювання аграрного ринку (Shpychak, 2007), розробку теоретичних основ трансформації сільського господарства в умовах ринкової економіки, просторового розвитку українського агробізнесу та формування інноваційної моделі функціонування агросектору, нових форм господарювання, проблеми сучасної аграрної політики в аспекті суспільно зумовлених функцій та цінностей (Yurchyshyn, 2007), (Korohodova \& Semenov, 2018), узагальнення та систематизація підходів щодо моніторингу агробізнесу України 3 метою оцінювання його поточного стану та перспектив функціонування в умовах глобалізації та трансформації економіки країни (Pohorielova, 2019), перспективи аграрного сектору економіки в контексті конкурентоспроможності вітчизняної аграрної продукції та зовнішньоекономічна діяльність агробізнесу України; аграрна політика (Kvasha, 2008), світоглядних питань щодо реалізації сталого розвитку територій аграрної спеціалізації (Khvesyk \& Isetskyi, 2008) та ін. Теоретико-методологічною основою розробки концепції суспільно-географічного дослідження виробничих процесів в сільському господарстві є праці провідних вчених-географів (Balabanov, 1994; Nahirna \& Savchuk, 2014; Oliynyk \& Stepanenko, 2003; Palamarchuk \& Iazynina, 1983; Pistun, 1997; Mezentseva \& Trusii, 2016; Zahorodnyi, 1985 та інші). Головні аспекти досліджень в різні роки зосереджувалися переважно на питаннях розвитку агропромислової інтеграції, агропродовольчого виробництва та агропродовольчої безпеки, функціональнокомпонентної структури АПК, зональності сільського господарства та аграрної функції сільської місцевості і багатьох інших. Вагомість отриманих наукових результатів незаперечна. Значна кількість окреслених проблем актуальні й нині. Проте, потребують подальших досліджень сучасні процеси, пов'язані 3 адміністративнотериторіальною реформою, актуалізацією ринку 
землі, трансформацією окремих господарських суб'єктів в системі агробізнесу тощо. Особливої наукової уваги сфера агробізнесу потребує також у зв'язку з низкою нових викликів та загроз, що набули гостроти. Йдеться про «пандемічні» еколого-економічні наслідки господарювання, про продовольчу безпеку, інвестиційно-інноваційні механізми впливу на агробізнес 3 метою прискорити «вихід» України на регіональні та світові ринки окремих видів сільськогосподарської продукції. Апріорі, даний науковий напрям $€$ одночасно як класично традиційним, так i постійно мінливим, що потребує актуалізації багатьох окремих аспектів дослідження.

Мета статті полягає в аналізі стану агробізнесу в Україні в контексті сучасних вимог та викликів, виявленні позитивних та негативних тенденцій його функціонування під впливом різноманітних чинників та визначенні основних стратегічних напрямків розвитку 3 метою підвищення конкурентоспроможності держави на світовому продовольчому ринку.

Методи дослідження. Здобуття нового знання багато в чому відбувається завдяки правильному застосуванню дослідником наукових методів пізнання, грамотне оперування якими дозволяє всебічно вивчити те чи інше явище, що становить предмет наукового інтересу, визначити його природу, встановити діалектичний зв'язок з іншими явищами та, в кінцевому рахунку, досягти поставленої дослідницької мети у розв’язанні наукової проблеми.

Саме в такому контексті вітчизняний агробізнес $€$ недостатньо дослідженою категорією суспільногеографічної науки. Дослідження проблем його розвитку в Україні є досить актуальним в площинах теорії i практики. 3 позицій теорії актуальність зумовлюється необхідністю грунтовного дослідження відносно нового і багатоаспектного поняття «агробізнес», а також, системи передумов та чинників його формування і розвитку. Зокрема, низки суспільно-географічних чинників: потреби у продукції АПК - місцеві, регіональні, загальнодержавні; рівень соціально-економічного розвитку; НТП; рівень урбанізації і формування систем розселення населення; забезпеченість трудовими ресурсами; рівень розвитку транспортної інфраструктури; відповідність і готовність державного управління та економічної політики. Традиційно важливим є врахування природно-географічнихумов та чинників: вплив рельєфу, кліматичних умов, грунтового покриву, водних ресурсів на виробничу спеціалізацію сільського господарства, заготівельної i переробної ланок АПК. 3 позицій географічної науки грунтовного підходу потребує багатоаспектність структури територіального АПК й агробізнесу - галузева, функціональна, територіальна, організаційно-управлінська.

Інструментом дослідження агробізнесу обрано систему філософських, загальнонаукових та спеціальних методів. Серед філософських методів, який вважається універсальним, був використаний діалектичний. Він дозволив виявити суперечливі протилежні тенденції у агробізнесовому процесі, зокрема конфлікт інтересів. Так, діяльність агробізнесу зазвичай спрямовується на отримання прибутку, тож вступає у конфлікт інтересів, наприклад, із соціальним розвитком села. Модель агробізнесу у вигляді діяльності, наприклад, фермерських господарств потенційно містить суперечності із корпоративною моделлю агробізнесу тощо.

Конкретизація наукового пізнання агробізнесу відбувалася завдяки застосуванню загальнонаукових методів, які прийнято поділяти на три групи: методи емпіричного дослідження (спостереження, порівняння, вимірювання, експеримент); методи, які застосовуються на емпіричному та теоретичному рівнях досліджень (абстрагування,аналіз та синтез, моделювання); методи теоретичних досліджень (ідеалізація, аксіоматичний метод, гіпотези та припущення, історичний метод, системний підхід) (Ponomarenko, 1999).

Сучасними напрямками розвитку агробізнесу є виробництво та реалізація безпечних, органічних продуктів, а також соціальна підтримка розвитку села. Зазначені сфери спрямовані саме на забезпечення здорового буття людини, що завжди становить певну цінність. Тому об'єктивне підгрунтя мало застосування ціннісного підходу як соціально виправданого нового методу дослідження агробізнесу.

Одним із конкретно-наукових методів дослідження агробізнесу обрано синергетичний. Доцільність його використання при дослідженні становлення та розвитку українського агробізнесу зумовлена тим, що, відповідно до синергетичного тлумачення світу, більшість систем, які існують у природі та суспільстві, належать до систем відкритого типу. Між ними постійно відбувається обмін енергією, речовинною інформацією, а тому для них характерна постійна мінливість і схоластичність (Shatkovska, 2009). Синергетичний метод дозволяє виявити характеристику самоорганізованих систем у стані нестабільності. Вказаний метод застосовувався для дослідження з урахуванням того, щоагробізнес має властивості самоорганізації i розглядається як система взаємозв'язків між різними суб'єктами, які можуть мати певну нестабільність; агробізнес перебуває під постійним впливом політичної, економічної, соціальної системи, що визначаються нестійкістю. До інструментарію вивчення агробізнесу були включені такі конкретно-наукові методи дослідження як соціологічний,статистичний, порівняльно-географічний, прогностичний.

Виклад основного матеріалу дослідження. Агробізнес - це локомотив української економіки, який завжди був однією 3 пріоритетних сфер для зовнішньота внутрішньо економічного розвитку країни, адже продовольче забезпечення своїх мешканців актуальне завжди. Від оптимального вирішення цього питання залежить як життєздатність та самодостатність суспільства, так i існування великої кількості найрізноманітніших напрямків людської діяльності. 
Аграрний сектор $€$ важливою стратегічною галуззю української національної економіки, яка забезпечує продовольчу безпеку та продовольчу незалежність держави, створює для частини сільського населення робочі місця. Незважаючи на певні досягнення у розвитку аграрної сфери, в Україні ще багато питань потребує вирішення. Крім традиційних проблем, що накопичувались роками, додались нові, безпрецедентні, над вирішенням яких розмірковує весь світ.

До ключових проблем у аграрному секторі України, що потребують нагального вирішення можна віднести: 1) карантинні обмеження, спричинені пандемією COVID-19; 2) зміни клімату і коливання погодних умов та їх вплив на виробництво сільськогосподарської продукції та ринкову кон'юнктуру; 3) адаптація вітчизняного агробізнесу до умов Європейського зеленого курсу (EU Green Deal); 4) стан ринку засобів виробництва для агробізнесу; 5) низький рівень затребуваності результатів аграрної науки; 6) нові споживчі мегатренди; 7) створення преференцій селянам-заробітчанам, що повернулись на малу Батьківщину через пандемію для реалізації власних бізнес-проектів з метою відродження села.

Пандемія, викликана вірусом Covid-19, та пов'язані з нею карантинні заходи, завдають великих економічних збитків практично у всіх галузях господарства України. Не є виключенням і аграрна сфера. Але, вочевидь, агросектор постраждає менше на відміну від інших сфер економіки України, адже базові цінності залишаться незмінними через постійну потребу у продуктах харчування.

В умовах пандемії найбільш відчутні зміни відбуваються у сфері аграрної логістики. Зокрема, тут мають місце такі тенденції як демпінгування цін через простої більшості транспортних засобів внаслідок зменшення завантаженості; зменшення кількості малих та середніх підприємств через банкрутство; підвищення попиту на ремонтні послуги транспортних засобів через невигідність придбання нових; електронна революція 3 метою оптимізації логістичних послуг; дотримання санітарних норм, дезінфекція обладнання та транспорту; зростання частки залізничних вантажних перевезень.

Карантин, оголошений у багатьох країнах світу, призводить до подорожчання логістичних ланцюгів. Карантинні вимоги, перевірки вантажів, що надходять в країну, позначаються на швидкості та вартості торгових операцій, що в свою чергу, призводить до падіння внутрішніх цін на сільськогосподарську продукцію на тлі подорожчання логістичного ланцюга. Не виключена загроза закриття транснаціональних коридорів для аграрної продукції.

Через подорожчання морської логістики під час пандемії українські експортери аграрної продукції отримують менше прибутків на ринках Азії. Транспортні компанії підняли ціни на свої послуги приблизно на 40\%, збільшивши собівартість продукції, яку Україна постачає морським шляхом в Азійський регіон, зокрема у Китай, Індонезію, Малайзію, Сінгапур, Гонконг, країни Перської затоки.
Пневмонія, що виникає внаслідок дії коронавірусу, стимулює попит на свіжі фрукти. Однак Україні складно конкурувати 3 іншими країнамиекспортерами 3 дешевою продукцією та більш сприятливим економіко-географічним положенням по відношенню до азійського ринку. Це сильно вплинуло на вітчизняних експортерів, зокрема, яблук, де й без того вартість логістики доходила до $30 \%$ (Zanuda, 2020).

Під час карантину мають місце адміністративні заходи, що безпосередньо впливають на сучасний стан вітчизняного агробізнесу. Зокрема, це трансформація каналів та способів реалізації сільськогосподарської продукції. Через заборону на діяльність продуктових ринків для дрібних фермерських та приватних господарств багато ринків збуту втрачено. Внаслідок цього дрібні товаровиробники були позбавлені можливості реалізувати свою продукцію, а споживачі - джерел постачання продовольчих товарів. Дрібні фермери та селяни опинились у скрутному фінансовому становищі. Результатом цього стала бартеризація відносин у сільській місцевості, що вказує на ознаки кризи у галузі. Водночас протягом карантину мало місце підвищення цін на сільськогосподарську продукцію з боку великих торговельних мереж та закупівельних фірм.

Внаслідок подальшого значного зниження доходів населення через втрату роботи, замороження заробітних плат, інфляційних процесів, зменшення кількості суб'єктів виробництва та реалізації сільськогосподарської продукції та інших чинників, пов'язаних із запровадженням карантинних заходів, має місце поступова зміна структури галузі та суттєві зрушення у попиті на продовольчі товари. Спостерігається зниження попиту на групи дорогих товарів 3 високою доданою вартістю (яловичина, дорогі сири, тепличні овочі тощо) (National Institute for Strategic Studies, 2020).

Пандемія сприятиме, разом 3 падінням цін на нафту, зниженню цін і на фуражне зерно. Адже вони прямо пов'язані з цінами на енергоносії через етанол, який виробляється 3 цукрової тростини та кукурудзи. Більшість заводів 3 виробництва біоетанолу зупинилась через неконкурентноздатність за умов низьких цін на нафту. Щоб запустити заводи з виробництва біоетанолу, треба знизити ціни на кукурудзу, яка є однією 3 основних зернових культур в Україні (Ianitskyi, 2021).

Стрімка зміна агрокліматичних умов в Україні, що проявляється у скороченні перехідних періодів, дефіциту вологи в грунті, повенях, теплових хвилях тощо, може вплинути на агробізнес у декількох напрямках: по-перше, українські фермери будуть змушені змінювати структуру посівних площ, а селекціонери - розробляти нові гібриди та сорти традиційних культур (пшениці, жита, кукурудзи, соняшника); по-друге, значну частку у структурі агровиробництва буде набирати вирощування нішевих та екзотичних культур; по-трете, стійке землеробство в сучасних кліматичних реаліях неможливе без моніторингу земель сільськогосподарського 
призначення за допомогою надійних супутникових даних та їх аналітики.

У зв'язку з глобальним потеплінням, частина регіонів України опинилась біля нижнього порогу субтропічного клімату. Це такі області, як Херсонська, Миколаївська, Запорізька, Одеська. Влітку 2020 року тут почали вирощувати не типові для України культури, такі як спеції (шафран, тим'ян, майоран) та бобові (нут, сорго, рижій). Все більшої популярності набуває вирощування амаранту, еспарцету, коноплі, деяких овочів (батат, бамія, артишок), фруктів, ягід, горіхів. Суттєвою перевагою природних умов України є можливість додавати до високих температур зрошення. Це відкриє необмежені можливості збирання декількох урожаїв на рік. Так, Чернігівська та Сумська області, які до цього часу не вважались особливо привабливими для сільського господарства, тепер демонструють одні з найкращих урожаїв по країні через поєднання двох факторів - підвищеної температури повітря та вологості грунтів. Селекціонери Інституту зрошувального землеробства Національної аграрної академії наук впевнені, що Україна повернеться до вирощування бавовнику, оскільки через зміни клімату Херсонська, Одеська, Миколаївська області тепер для цього підходять якнайкраще.

Черговим викликом та посиленням вимог до українського агробізнесу є адаптація законодавства, нормативної бази та технологій до Європейського зеленого курсу (EU Green Deal), згідно 3 яким Європейський континент повинен стати нейтральним до змін клімату до 2050 року.

Зелений курс був представлений Європарламентом в кінці 2019 року, одним з ключових питань якого є стійка аграрна політика (стратегія від лану до столу). Водночас курс має стимулювати розвиток економіки, покращити здоров'я та якість життя людей. У аграрній частині даний документ посилається на оновлену стратегію «від ферми до виделки», в українській інтерпретації «від лану до столу», і передбачає до 2030 року скоротити використання небезпечних пестицидів у рослинництві та антибіотиків у тваринництві до 50\%, а також розширити частку органічного землеробства до 25\% від загального, зменшити використання добрив на $20 \%$ та внесення поживних речовин в грунт на $50 \%$.

Ці вимоги є потужним викликом вітчизняному агробізнесу, обсяги виробництва якого на 10-50\% нижче ніж в тих країнах, які сприймаються як певні оріснтири (Mission of Ukraine to the European Union, 2021).

Україна має певні стартові позиції щодо впровадження Зеленого курсу. Так, ще у 2013 році у Дніпропетровській та Вінницькій областях почали втілюватись проекти 3 виробництва органічних добрив. Це дало можливість започаткувати деяким агрофірмам екологічно чистий бренд виробництва овочевої продукції Органік-Д (борщовий набір овочів) із значно нижчим за норму вмістом нітратів та пестицидів. В частині впровадження вимог Європейського зеленого курсу підписана угода $з$ компанією «Сингента» щодо дослідження впливу парникових газів на довкілля, які будуть здійснюватись на цих підприємствах.

Зелений курс $є$ одночасно i викликом, i можливістю перетворити Україну на одного 3 гарантів світової продовольчої безпеки та країну 3 диверсифікованим агроекспортом. Важливим кроком до цього стало приєднання держави у березні 2021 року до Глобального партнерства 3 біоенергетики, стратегічним партнером якого є Продовольча та сільськогосподарська організація ООН (FAO). Така співпраця щодо подальшого розвитку біоенергетики може суттєво вплинути на вирішення кліматичних викликів, зокрема декарбонізацію, продовольчу безпеку та сталий розвиток вцілому. Україна має потужний аграрний потенціал і саме тому галузь біоенергетики є дуже перспективною.

Ключовою умовою для агровиробників $\epsilon$ постійна та безперебійна робота техніки. Проте пандемія відчутно вплинула на їі дистрибуцію та продаж. I така ситуація склалась в усьому світі.

Через значну зношеність сільськогосподарської техніки у вітчизняних аграрних підприємствах (за різними підрахунками 50-80\%), Україна $\epsilon$ привабливим ринком для зарубіжних виробників. Найбільша імпортозалежність спостерігається по таких позиціях як: трактори, комбайни, самохідні оприскувачі, плуги, борони, сівалки тощо. Через продовження карантинних заходів актуальною залишається проблема закриття чи обмеження роботи багатьох заводів-виробників сільськогосподарської техніки як в Україні, так і за їі межами. Одночасно ускладнюється логістика через затримку на кордонах. В результаті зростають терміни поставок продукції або i, взагалі, унеможливлюють їх, підвищується вартість комплектуючих. Відсутність у дрібних виробників обігових коштів також негативно позначається на придбанні сільськогосподарської техніки. Скорочення обсягів продажів вітчизняної та імпортної агротехніки прогнозується на рівні 15-20\%. А відтак в нинішній ситуації подальший розвиток отримають лізінгові схеми купівлі-продажу сільськогосподарської техніки. (Business.ua, 2020).

Через недостатню фінансову спроможність, дрібні фермери будуть більш вразливими щодо відчуження власної землі та засобів виробництва. Це вплине на подальше посилення монополістичних тенденцій у сільському господарстві. Альтернативою $€$ об'єднання малих фермерських господарств 3 метою протидії великим агрохолдингам (Hromadskyi Prostir, 2020; Iakovenko, 2020; Agravery.com, 2020).

Захист рослин від шкідників та хвороб $\epsilon$ невід'ємною складовою сучасного агровиробництва в Україні, незважаючи на досить широке поширення органічного землеробства у сільському господарстві багатьох країн світу. Для цього використовуються різні види пестицидів, витрати на які поки залишаються однією з суттєвих статей собівартості виробництва продукції рослинництва, що впливає на його прибутковість. Розвиток органічного землеробства в Україні не виключає повну чи часткову відмову від пестицидів. Часто вітчизняні виробники 
використовують діючі речовини, які включені до переліку заборонених діючих речовин в СС. На жаль від їх використання поки неможливо відмовитись через відсутність конкурентоспроможних аналогів. В Україні поки не ведеться активна робота щодо невикористання препаратів, що несуть загрозу для людей та довкілля.

Суттєву загрозу виробництву безпечної для здоров’я людини споживчої продукції становить засилля фальсифікату на ринку засобів захисту рослин. За різними підрахунками, сьогодні на внутрішньому ринку України 25-30\% засобів захисту рослин - це фальсифікат, а там де є сегмент дрібної розфасовки - 90\% (Infoindustria, 2021).

Фальсифікат виробляється в основному в середині країни шляхом повторного використання упаковки; поверненням на ринок заборонених та вилучених пестицидів; перепакуванням застарілих отрутохімікатів. Часто не якісні засоби захисту рослин стрімко зростають в ціні.

Дана ситуація потребує нагального вирішення через контроль та регулювання ринку пестицидів, зокрема, шляхом боротьби 3 контрафактом та неякісною продукцією.

Покращенню стану справ у даній сфері агробізнесу може сприяти відкриття в середині 2018 року у Черкасах наукової платформи світового рівня Науково-дослідного інституту «Інститут здоров’я рослин» (Crop Care Institute). Цей унікальний проект дозволить аграріям будувати свій бізнес на основі іноваційних технологій. Функціонально він поєднав фундаментальні та галузеві дослідження, агробіологічний сервіс та навчально-наукову роботу. Всі розробки тестуватимуть в унікальному демоцентрі, який являє собою комплекс підземних теплиць, фітотронних кімнат та кліматичних камер. Протестовані препарати запускатимуть у виробництво на «Фабриці агрохімікатів». Інститут працюватиме у форматі “Greenchemistry" (зелена хімія) - підхід, який передбачає дбайливе ставлення до природи і максимальне зменшення використання шкідливих компонентів.

Ключове значення для забезпечення продуктивності агровиробництва має стан ринку мінеральних добрив. У 2013 році держава перебувала у першій світовій десятці звипуску азотних добрив i мала шестивідсоткову частку на ринку аміаку. Однак, після 2014 року їх виробництво стало неконкурентноздатним і різко скоротилось. Одночасно значно зросли імпортні поставки, переважно 3 Росії. У 2019 році до російських постачальників мінеральних добрив були застосовані санкції, що призвело до значного скорочення українського ринку. Ситуацію ускладнює ще й той факт, що частина потужностей з виробництва азотних добрив опинилась на тимчасово окупованій території Донбасу.

Нестабільна ситуація в країні призвела до скорочення посівних площ та зниження попиту на добрива. Фермери почали відмовлятись від профілактики грунтів та менше використовувати мінеральних добрив. Відбувається переорієнтація
3 дорогих мінеральних добрив на більш дешеві аналоги або на добрива тваринного або органічного походження.

Вирішенню питання забезпечення мінеральними добривами може сприяти освоєння українськими хімічними підприємствами технологій випуску добрив наступного покоління - це безбаластні водорозчинні мінеральні добрива, призначені для внесення в грунт в процесі поливу або крапельного зрошення. Освоєння цієї швидкозростаючої ніші допоможе Україні забезпечити добривами внутрішній ринок i знову стати їх провідним експортером (Kapitanska \& Polianchykov, 2020).

Важливу роль в успішному реформуванні аграрного сектору відіграє галузева наука. Зараз в інтересах агросектору працює понад 11 тисяч науковців (15\% загальної чисельності наукових співробітників країни). Аграрний сектор обслуговує державна Українська академія аграрних наук, в складі якої понад 120 наукових установ. Її доповнює добре розвинена система навчальних закладів (Verkhovna Rada of Ukraine, 2019).

Проблема полягає у низькому рівні затребуваності результатів аграрної науки сільськогосподарським виробництвом. Це призводить до погіршення якості ㄲi функціонування. Переважання середніх та дрібних фермерських господарств унеможливлює використання сучасних дорого вартісних технологічних та технічних засобів виробництва. Одночасно в агросекторі посилюється тенденція скуповування торговельним, фінансовим та промисловим капіталом корпоративних прав засновників сільськогосподарських підприємств, що веде до відчуження значної кількості угідь із сільськогосподарського виробництва.

Аграрна наука в значній мірі є відірваною від сільськогосподарського виробництва та слабко комерціалізованою через переважання державного фінансування, що суперечить світовому досвіду. У розвинених країнах аграрна наука $є$ найбільш комерціалізованим сектором наукових досліджень.

Певну новизну у розвиток вітчизняного агробізнесу вже сьогодні вносить підприємництво в рамках світового маркетингового мегатренду Superfood, що спеціалізується на виробництві продукції переважно рослинного походження, концентрація корисних речовин в яких дуже висока; це овочі, коріння, насіння, горіхи, листова зелень, ягоди тощо. Найновіший тренд здорового харчування - мікрозелень (мікрогрін), а ii вирощування стає популярним видом агробізнесу. Багато видів ягід, овочів та фруктів перейшли зараз у категорію «суперфудів» через свої корисні властивості, а проголошення 2021 року ООН роком овочів та фруктів може ще більше привернути увагу як споживачів, так i аграріїв до важливості цих продуктів в раціоні харчування.

За останні декілька років зросли площі під овочевими та ягідними культурами, а обсяги інвестицій у плодоовочевий сегмент, зокрема у виробництво продукції з високою доданою вартістю (вирощування грибів, зелені, ягід, продукція 
закритого грунту) прискорюється. Не зважаючи на пандемію коронавірусу, зниження доходів населення та ускладнення логістики, торгівля плодоовочевою продукцією категорії «суперфуд» процвітає. Адже люди переймаються своїм здоров'ям, що є однією 3 головних причин різкого зростання споживання корисних ягід та фруктів.

В Україні все більшої популярності набувають фермерські продукти, що виготовляються маленькими партіями за індивідуальними рецептами (крафтові продукти), які не тільки цікавіші за смаком, а й здоровіші. В них не додають підсилювачів смаку, барвників чи інших речовин, які в умовах масових виробництв дозволяють здешевити вартість, а тому коштують дорожче.

Розвиток крафтового виробництва зараз активізується, оскільки завжди є споживачі, яких цікавить певна локальна ідентичність, технологічна унікальність та якість продукції, навіть по вищій ціні.

Разом 3 виробництвом локальної крафтової сільськогосподарської продукції зростає інтерес до українських нішевих продуктів. Все більшого значення набувають поняття простежуваності продукту від лану до столу, географічна адресність походження продукту, безпечність та якість продукції, питання сертифікації продукції за міжнародними стандартами.

Осередки нішових інновацій, які поєднують старовинні традиції та сучасні технології створення корисних для здоров'я продуктів, сформувались майже в усіх регіонах України та охоплюють різноманітні сегменти агробізнесу (виробництво меду, сиру, чаю, амарантової та конопляної продукції тощо). Так, у Київській області започатковано вирощування до недавно забутої в Україні культури чуфи (земляний мигдаль) та виробництво 3 нього кондитерських виробів. Недалеко від столиці фермери освоїли вирощування лагенарії (декоративний гарбуз) 3 подальшим виробництвом декоративних світильників та люстр.

Яскравий приклад нішевого бізнесу - компанія «Стодола», що знаходиться у Миколаївській області. Тут не тільки вирощують незвичайні для України овочі: кавуновий огірок, скорцену, рогатий огірок ківано, кольрабі, мангольд, трюфельну картоплю та різноманітні бебі-овочі, а й займаються виготовленням крафтової консервації. У Черкаській області відроджуються старовинні рецепти виробництва хлібців з лободи, кропиви та материнки. Цілющі трав'яні чаї виробляють у Закарпатській області та ще й медове драже за ексклюзивною технологією. У Харківській області почали створювати унікальний косметичний продукт - екологічно чисте мило та шампунь на основі козячого молока на базі науковоекспериментальної ферми «Святогірська коза». Сумська область прославилась виготовленням пельменів 3 м'ясом равлика, так як равликові ферми досі залишаються крафтовим напрямом та вигідною нішею в Україні (Zvierieva, 2020).

Теми українського крафту, ніш та локальних продуктів варті всебічної уваги з метою підтримки українських агровиробників, підвищення якості продукції, плеканні українських традицій у виробництві нових продуктів.

Зменшенню негативного впливу наслідків карантину, відродженню сільської місцевості, створенню робочих місць, стимулюванню агровиробництва може сприяти вимушене повернення селян-заробітчан з-за кордону та приплив міських жителів, що опанували навички роботи у дистанційних умовах.

Селяни, що виїхали в свій час на заробітки, мають досвід стандартів якості заможного життя, усвідомлення власних реальних потреб, а також у більшості своїй володіють необхідними знаннями та навичками для реалізації власних бізнес-проектів на своїй малій Батьківщині. Такі особи можуть стати лідерами та своїм прикладом вплинути на трансформацію сільського світогляду.

Частина міських жителів, що 3 метою економії перебралась до своїх домівок, вочевидь, залишиться в селі після завершення карантину, адже пандемія коронавірусу прискорила впровадження тенденцій дистанційної роботи, а деякими компаніями та їх працівниками було вкладено інвестиції у необхідне обладнання, інфраструктуру, програмне забезпечення, оволодіння новими навичками.

За викликом часу потреба України використовувати найкращий європейський науковий та аграрний досвід була реалізована також в рамках 23-го саміту Україна - ЄС, що проходив 12 жовтня 2021 року у Києві. Ця подія підтвердила прагнення обох сторін розвивати інтеграцію та сприяти співпраці в різних секторах економіки, у тому числі, у галузі науки,торгівлі, екологічної взаємодії; відповідно, попередні досягнення та результати на цьому шляху були схвально сприйняті. Зокрема, привітали започаткування діалогу щодо Свропейського зеленого курсу та зеленого переходу України. Сторона ЄС схвалила прагнення України наблизити законодавство до Європейського зеленого курсу та підтвердила свою прихильність у підтримці України у цих зусиллях за допомогою широкого спектру співпраці 3 міжнародними фінансовими інституціями. Сторона СС привітала затвердження Україною Національно визначеного внеску за Паризькою угодою та запропонувала Україні ухвалити довгострокову стратегію низьковуглецевого розвитку, з обов'язковою метою щодо досягнення кліматичної нейтральності не пізніше 2050 року; також було запропоновано впроваджувати реформи, які сприятимуть та прискорюватимуть зелений перехід держави, що має відобразитися у тому числі, на зміцненні позицій агробізнесу, прагматичної взаємодії в науковій сільськогосподарській сфері та екологічної співпраці.

Висновки. На основі аналізу сучасного стану розвитку агробізнесу в Україні виявлено, що його стійкий розвиток у перспективі можливий на основі загальнонаціональної стратегії при активній державній підтримці.

На негативні тенденції щодо розгортання інноваційної діяльності у агробізнесі впливає 
низький рівень фінансового забезпечення дрібних виробників, а також недоступність технічних засобів, численне посередництво між виробником та споживачем, непідйомні кредити на придбання засобів виробництва.

Україна все ще не має відкритого доступу на ринок Європейського Союзу 3 багатьма видами агропродукції, зокрема йдеться про яловичину, свинину та, навіть, картоплю. Розмір квот і мит у даному випадку просто не відіграє важливого значення. Як відомо, з метою розширення експорту необхідно пройти аудит системи контролю; лише після цього Україна з'явиться в переліку держав, 3 яких дозволений імпорт до ЄС. Цей механізм відповідно, створює можливість сертифікувати на експорт окремі підприємства українського сільськогосподарського ринку.

«Зелений курс», започаткований та підтверджений результатами 23-го саміту Україна - $С$, $є$ одночасно і викликом, і можливістю перетворити Україну на одного з гарантів світової продовольчої безпеки $з$ диверсифікованим агроекспортом.

Важливою позитивною умовою відродження села взагалі та активізації розвитку агробізнесу, зокрема, є створення для контингенту громадян, що повертаються 3 «заробітків» і бажають розпочати власну господарську діяльність, необхідних префе- ренцій, які б стимулювали організацію бізнесу саме в Україні. Такі осередки агробізнесу могли б не лише зменшити негативний вплив наслідків карантину, а й мати довготривалий ефект розвитку сільської місцевості, ставши його каталізатором.

Суттєвий вплив на розвиток вітчизняного агробізнесу може мати підприємництво в рамках світового маркетингового мегатренду Superfood 3 виробництва продукції переважно рослинного походження, концентрація корисних речовин в яких дуже висока (овочі, коріння, насіння, горіхи, листова зелень, ягоди тощо).

Українські крафтові виробники все активніше долучаються до міжнародного руху Slowfood, який рятує біорізноманіття продуктів, рецептів та страв у світі. Це відкриває вітчизняним виробникам можливості участі у закордонних фестивалях та ще більше популяризувати місцеву сільськогосподарську продукцію. Споживання продукції локальних фермерів позитивно впливає на місцеву економіку. Свої доходи виробники часто інвестують у місцеві громади, покращуючи стан інфраструктури та створюючи робочі місця. При цьому слід використовувати вітчизняний та зарубіжний досвід, враховуючи його специфіку, яка визначається значною динамікою та впливом як традиційних, так і нових чинників.

\section{References:}

Agravery.com (2020). Ukrainian agricultural holdings are recovering after the fall due to the coronavirus. Access mode: https://agravery.com/uk/posts/show/ukrainski-agroholdingi-vidnovluutsa-pisla-padinna-cerez-koronavirus. [In Ukrainian]. [Українські агрохолдинги відновлюються після падіння через корона вірус / Agravery.com. Режим доступу: https://agravery.com/uk/posts/show/ukrainski-agroholdingi-vidnovluutsa-pisla-padinna-cerez-koronavirus]

Balabanov, G. (1994). The influence of the agro-industrial complex on the social development of the territory. In Problems of Complex Bevelopment of the Territory (pp. 147-165). Kуiv, Naukova Dumka. [In Ukrainian]. [Балабанов Г. В. Влияние агропромышленного комплекса на социальное развитие территории / Проблемы комплексного развития территории. Киев: Наукова думка, 1994. С. 147-165.]

Business.ua (2020). The deficit suggested: the market for agricultural machinery has shrunk significantly under pandemic restrictions. Access mode: https://business.ua/uk/defitsit-naviyalo [Дефіцит навіяло: ринок сільгосптехніки в карантин значно скоротився / Веб-портал Business.ua. Режим доступу: https:/business.ua/ uk/defitsit-naviyalo]

Hromadskyi Prostir (2020). Quarantine as a push to unite small farmers and work together to find solutions. Access mode: https://www.prostir.ua/?news=karantyn-yak-poshtovh-dlya-objednannya-malyh-fermeriv-i-spilnohoposhuku-rishen [In Ukrainian]. [Карантин як поштовх для об'єднання малих фермерів і спільного пошуку рішень / Громадський Простір. Режим доступу: https://www.prostir.ua/?news=karantyn-yak-poshtovh-dlya-objednannyamalyh-fermeriv-i-spilnoho-poshuku-rishen]

Iakovenko, R. (2020). Quarantine as a mechanism for monopolization of agriculture. Narodne Slovo. Access mode: https://bit.ly/2CVHDJI. [In Ukrainian]. Яковенко Р. Карантин як механізм монополізації сільського господарства / Народне слово. Режим доступу: https://bit.ly/2CVHDJI]

Ianitskyi, A. (2021). Grain is more important than oil: what awaits agriculture after quarantine? Hromadske TV Web Portal. Access mode: https://hromadske.ua/posts/zerno-vazlivish-za-naftu-sho-chekaye-silske-gospodarstvopislya-karantinu [In Ukrainian]. [Яніцький А. Зерно важливіше за нафту: що чекає сільське господарство після карантину / Громадське телебачення: веб-портал. Режим доступу. https:/hromadske.ua/posts/zerno-vazlivishza-naftu-sho-chekaye-silske-gospodarstvo-pislya-karantinu]

Infoindustria (2021). Is the pesticide market in Ukraine regulated? Access mode: https://infoindustria.com. ua/chi-vregylovano-runok-pestitsidov-v-ukraini [In Russian]. [Чи врегульовано ринок пестицидів в Україні? / Инфоиндустрия. [Режим доступа]: https://infoindustria.com.ua/chi-vregylovano-runok-pestitsidov-v-ukraini]

Kapitanska, O., \& Polianchykov, S. (2020). Starting fertilizers - strategic management of plant nutrition. Infurrow.in.ua. Access mode: [In Ukrainian]. [Стартові добрива - стратегічне управління системою живлення / In-furrow.in.ua. Режим доступу: https://in-furrow.in.ua/about-us/] 
Khorunzhyi, M. (2006). Capitalization of agriculture and modern state agricultural policy. Agricultural Economy, 7, 64-67. [In Ukrainian]. [Хорунжий М. Капіталізація сільського господарства та сучасна державна аграрна політика. Економіка АПК. 2006. № 7. С. 64-67.]

Khvesyk, M., \& Isetskyi, A. (2008). Food Security of Ukraine. Kyiv: NAS of Ukraine. [In Ukrainian]. [Хвесик M. А., Ісецький А. С. Продовольча безпека України. К.: РВПС НАН України, 2008. 160 с.]

Korohodova, O., \& Semenov, V. (2018). Ukrainian agribusiness: principles of spatial development based on transnationalization processes. Economic Bulletin of Kyiv Polytechnic Institute, 15, 165-172. [In Ukrainian]. [Корогодова О. О., Семенов В. Ф. Засади просторового розвитку українського агробізнесу з урахуванням процесів транснаціоналізації // Економічний вісник Національного технічного університету України «Київський політехнічний інститут». 2018. № 15. С. 165-172.

Kvasha, S. (2008). WTO and the priorities of agricultural economics. Agricultural Economy, 5, 4-9. [In Ukrainian]. [Кваша С. М. СОТ та пріоритети аграрної економічної науки // Економіка АПК. 2008. № 5. С. 4-9.]

Melnyk, L., Makarenko, P., \& Melnyk, L. (2010). Factors influencing the profitability of agricultural enterprises. Agricultural Economy, 6, 83-86. [In Ukrainian]. [Мельник Л. Ю., Макаренко П. М., Мельник Л. Л. Фактори впливу на прибутковість аграрних підприємств // Економіка АПК. 2010. № 5. С. 83-86.]

Mesel-Veseliak, V. (2016). Improving the efficiency of agricultural production. Agricultural Economy, 6, $17-$ 22. [In Ukrainian]. [Месель-Веселяк В. Я. Підвищення ефективності сільськогосподарського виробництва // Економіка АПК. 2016. № 12. С. 17-22.]

Mezentseva, N., \& Trusii, O. (2016). Geography of the Agrarian Industrial Complex. Kyiv, Kyiv University Publishing House. [In Ukrainian]. [Мезенцева Н. I., Трусій О. М. Географія аграрно-промислового комплексу: навч.-метод. посіб. К.: ВПЦ «Київський університет», 2016. 92 с.]

Mission of Ukraine to the European Union (2021). European Green Deal. Access mode: https://ukraine-eu.mfa. gov.ua/en/2633-relations/galuzeve-spivrobitnictvo/klimat-yevropejska-zelena-ugoda

Nahirna, V., \& Savchuk, I. (2014). Possible threats to agriculture in Ukraine from the standpoint of environmental safety. Economy of Ukraine, 2(627), 71-83. [In Ukrainian]. [Нагірна В. П., Савчук І. Г. Можливі загрози сільському господарству України з позицій екобезпеки // Економіка України. 2014. Вип. 2. № 627. С. 71-83.]

National Institute for Strategic Studies (2020). Regarding urgent measures to support small farms. Access mode: https://niss.gov.ua/sites/default/files/2020-04/fermerski-gospodarstva.pdf [In Ukrainian]. [Concerning urgent measures to support small farms and farms. Режим доступу: https://niss.gov.ua/sites/default/files/2020-04/fermerskigospodarstva.pdf]

Oliynyk, Y., \& Stepanenko, A. (2003). Social Development of the Villages and Rural Areas. Kyiv, Obrii. [In Ukrainian]. [Олійник Я. Б., Степаненко А. В. Соціальний розвиток села і територій сільського типу: Навч. посібник К.: ВГЛ Обрії, 2003. 128 с.].

Orlatyi, M. (ed.) (2012). Rural social infrastructure: modern state and prospects. Kyiv, Ukragropromproduktyvnist, State Statistics Service of Ukraine, National Academy of the President of Ukraine. [In Ukrainian]. [Соціальна інфраструктура села: сучасний стан та перспективи: монографія / Укр. НДІ продуктивності АПК, Держ. служба статистики України, Нац. акад. держ. упр. при Президентові України; [авт.-упоряд.: М. К. Орлатий та ін.; за ред. М. К. Орлатого]. К.: НДІ «Украгропромпродуктивність», 2012. 249 с.

Palamarchuk, M., \& Iazynina, R. (1983). Specialized agro-industrial complexes and methodological foundations of their economic and geographical research. Geography and natural resources, 4, 12-19. [In Russian]. [Паламарчук М. М., Язынина Р. А. Специализированные агропромышленные комплексы и методические основы их экономико-гсографического исследования // География и природ. ресурсы. 1983. №4. С. 12-19.]

Paskhaver, B. (ed.) (2009). Challenges and ways of agri-food development. Kyiv, Institute of Economics and Forecasting. [In Ukrainian]. [Виклики і шляхи агропродовольчого розвитку / Пасхавер Б. Й., Шубравська О. В., Молдаван Л. В. та ін.; за ред. акад. УААН Б.Й.Пасхавера; НАН України; Інститут економіки та прогнозування. K., 2009. 432 c.].

Pistun, М. (1997). Geography of agro-industrial complexes. Kyiv, Lybid. [In Ukrainian]. [Пістун М. Д. Географія агропромислових комплексів. Київ: Либідь, 1997. 198 с.

Pohorielova, T. (2019). Statistical aspects of agribusiness monitoring of Ukraine. Bulletin of Socio-Economic Research, 69(1), 58-67. Doi: 10.33987/vsed.1(69).2019.58-67 [In Ukrainian]. [Погорєлова Т. В. Статистичні аспекти моніторингу агробізнесу України // Вісник соціально-економічних досліджень. 2019. №1. С. 58-67.]

Ponomarenko, L. (1999). How to prepare and defend a dissertation for a degree. Kyiv: Higher Attestation Commission of Ukraine. [In Ukrainian]. [Пономаренко Л. А. Як підготувати і захистити дисертацію на здобуття наукового ступеня. Методичні поради. К.: Редакція «Вищої атестаційної комісії України», 1999. 80 с.]

Radchenko, O. (2017). Budget 2017: mechanisms and instruments for agricultural support. Agro-business.com. ua. Access mode: http://agro-business.com.ua/agro/pytannia-bukhhalterii/item/1774-mekhanizm-ta-instrumentypidtrymky-silskoho-hospodarstva-zhidno-z-biudzhetom-na-2017-rik.html [In Ukrainian]. [Механізм та інструменти підтримки сільського господарства згідно з бюджетом на 2017 рік. Agro-business.com.ua. Режим доступу: http://agro-business.com.ua/agro/pytannia-bukhhalterii/item/1774-mekhanizm-ta-instrumenty-pidtrymky-silskohohospodarstva-zhidno-z-biudzhetom-na-2017-rik.html]

Sabluk, P. (2001). Agrarian Economy and Politics in Ukraine: The Results of the Past and a Look into the Future. Volume 1. Kyiv, Institute of Agrarian Economy. [In Ukrainian]. [Саблук П. Т. Аграрна економіка і політика в 
Україні: підсумки минулого і погляд у майбутнє. К.: IAE УААН. 2001. Т.1. 380 с.].

Shatkovska, G. (2009). Synergetics as a method of studying complex open systems. Collection of scientific works of Ogienko Kamyanets-Podilsky National University. Pedagogical Series, 15, 331-334. [In Ukrainian]. [Шатковська Г. I. Синергетика як метод дослідження складних відкритих систем. Збірник наукових праць Кам’янецьПодільського національного університету імені Івана Огієнка. Серія:Педагогічна. 2009. Вип. 15. С. 331-334]

Shpychak, O. (2007). Real assessment of the economic condition of the agro-industrial complex of Ukraine as a necessary precondition for its exit from the crisis. Agricultural Economy, 5, 26-30. [In Ukrainian]. [Шпичак О.М. Реальна оцінка економічного стану АПК України як необхідна передумова виходу його 3 кризи // Економіка АПК. 2007. № 5. С. 26-30.]

Verkhovna Rada of Ukraine (2019). Strategy of innovative development of Ukraine - 2030. Access mode: https://zakon.rada.gov.ua/laws/show/526-2019-\%D1\%80\#Text [In Ukrainian]. [Стратегія інноваційного розвитку України на період до 2030 року. Режим доступу: https://zakon.rada.gov.ua/laws/show/526-2019-\%D1\%80\#Text].

Yurchyshyn, V. (2017). Some generalizations and problems of modern agrarian policy. Agricultural Economy, 4, 12-18. [In Ukrainian]. [Юрчишин В. В. Деякі узагальнення і проблеми сучасной аграрної політики // Економіка АПК. 2017. № 4. С. 12-18.]

Zagorodnyi V. (1985). Features of rural settlement in the Kyiv Dnieper region. In Economic Geography of the Development of Production and Settlement in the Kyiv Dnieper Region (pp. 38-46). Kyiv, Kyiv State Polytechnic Institute. [In Ukrainian]. [Загородний В. В. Особенности сельского расселения в Киевском Приднепровье / Экономико-географические аспекты развития производства и расселения в Киевском Приднепровье: Сб. науч. трудов. К.: КГПИ, 1985. С. 38-46.]

Zanuda, A. (2020). Coronavirus, quarantine and drought: will Ukraine have bread this year? BBC News Ukraine. Access mode: https://www/bbc.com/Ukrainian/Features-52441162 [In Ukrainian]. [Коронавірус, карантин та посуха: чи буде Україна з хлібом цього року? Веб-портал BBCNews Україна. Режим доступу: https://www/bbc. com/Ukrainian/features-52441162]

Zvierieva, K. (2020). Local, niche and kraft products shaping tastes in Ukraine. Agri-Gator. Access mode: https://agri-gator.com.ua/2020/10/30/lokalni-nishovi-ta-kraftovi-produkty-formuiut-smak-ukrainy-kateryna-zvieriev a/?fbclid=IwAR2E3GiJy8FZ41JFHzggsIp4jE6gnEKZjTLKpuvmVJEjCglSIjyQIxY8Yi4 [In Ukrainian]. [Звєрєва K. Локальні, нішеві та крафтові продукти формують смак України. Веб-портал Agri-Gator. Режим доступу: https://agri-gator.com.ua/2020/10/30/lokalni-nishovi-ta-kraftovi-produkty-formuiut-smak-ukrainy-kateryna-zvieriev a/?fbclid=IwAR2E3GiJy8FZ41JFHzggsIp4jE6gnEKZjTLKpuvmVJEjCg1SIjyQIxY8Yi4] 